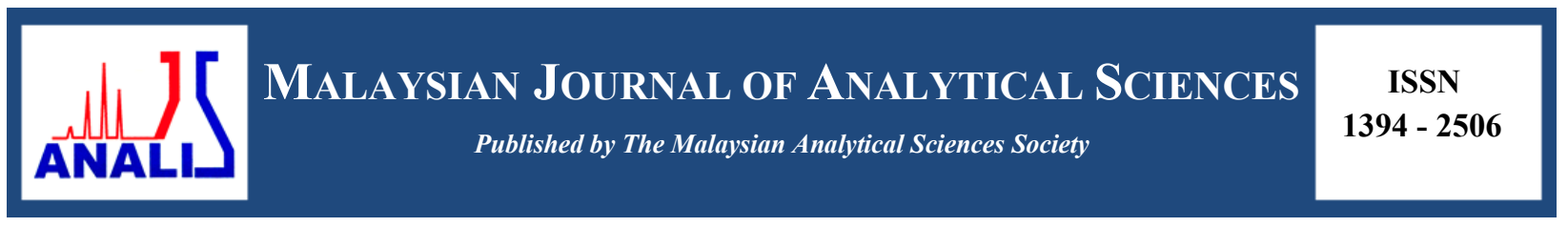

\title{
ADSORPTION OF CADMIUM (II) IONS BY POLYACRYLONITRILE- BASED ACTIVATED CARBON NANOFIBERS/MAGNESIUM OXIDE AS ITS ADSORBENTS
}

\author{
(Karbon Nano-Gentian Teraktif Berasaskan Poliakrilonitril/Magnesium Oksida Sebagai \\ Penjerap untuk Penjerapan Ion Kadmium (II))
}

Faten Ermala Che Othman, Norhaniza Yusof*, Juhana Jaafar, Ahmad Fauzi Ismail, Norfadhilatuladha Abdullah, Hasrinah Hasbullah

Advanced Membrane Technology Research Center,

Faculty of Chemical and Energy Engineering,

Universiti Teknologi Malaysia, 81310 Johor Bahru, Johor, Malaysia

*Corresponding author: norhaniza@petroleum.utm.my

Received: 21 October 2015; Accepted: 14 June 2016

\begin{abstract}
In this work, activated carbon nanofibers (ACNFs) from precursor polyacrylonitrile (PAN) and magnesium oxide (MgO) were prepared via electrospinning process. The morphological properties of the PAN/MgO-based ACNFs were characterized by using Scanning Electron Microscopy (SEM) and the specific surface area (SSA) were investigated using nitrogen adsorption, Brunauer-Emmett-Teller (BET) methods. Moreover, the functional groups were analyzed by using Fourier Transform Infrared (FTIR). Besides that, the sorption study has been conducted in order to determine the adsorption capacity between electrospun ACNFs/MgO, pristine ACNFs and granular activated carbon (GAC) towards cadmium (II) ions. The results showed that the SSA of modified ACNFs $\left(198.80 \mathrm{~m}^{2} / \mathrm{g}\right)$ is significantly higher compared to the precursor ACNFs $\left(15.43 \mathrm{~m}^{2} / \mathrm{g}\right)$, however the SSA obtained is quite lower compared to the average theoretical value. SEM micrograph of pristine ACNFs depicted more compact nanofibers compared to aligned nanofibers with average diameter of 200-700 nm. Under batch adsorption study, it was found out that $\mathrm{Cd}(\mathrm{II})$ removal of both $\mathrm{ACNF}$ and $\mathrm{ACNFs} / \mathrm{MgO}$ is higher compared to the commercial GAC. It has been demonstrated that the adsorption capacity of both electrospun ACNFs (ACNFs/MgO and pristine ACNFs) is higher when compared to the adsorption capacity of commercial GAC towards Cd (II) ions.
\end{abstract}

Keywords: polyacrylonitrile, activated carbon nanofiber, magnesium oxide, cadmium (II) ion adsorption

\section{Abstrak}

Kajian ini membincangkan tentang proses penyediaan karbon nano-gentian teraktif (ACNFs) berasaskan poliakrilonitril (PAN) dan magnesium oksida $(\mathrm{MgO})$ melalui teknik putaran elektro. Ciri-ciri morfologi bagi ACNFs telah dicirikan menggunakan Mikroskopi Elektron Pengimbasan (SEM) dan luas permukaan kawasan tertentu (SSA) telah disiasat menggunakan kaedah penjerapan nitrogen, Brunauer-Emmett-Teller (BET). Selain itu, kumpulan berfungsi dianalisis dengan menggunakan Inframerah Transformasi Fourier (FTIR). Melalui kajian ini juga, kapasiti penjerapan diantara ACNFs, ACNFs/MgO dan karbon berbutir teraktif (GAC) terhadap ion (II) kadmium telah dijalankan. Hasil kajian menunjukkan bahawa SSA daripada ACNFs yang telah diubah suai $\left(198.80 \mathrm{~m}^{2} / \mathrm{g}\right)$ adalah lebih tinggi berbanding dengan pelopor ACNFs $\left(15.43 \mathrm{~m}^{2} / \mathrm{g}\right)$, walau bagaimanapun SSA yang diperoleh agak rendah berbanding dengan nilai purata teori. SEM mikrograf bagi pelopor ACNFs menunjukkan nano-gentian yang lebih padat berbanding nano-gentian berstruktur sejajar dengan diameter purata 200-700 nm. Di bawah kajian penjerapan berkumpulan, pembuangan ion (II) kadmium bagi kedua-dua ACNFs dan ACNFs/MgO adalah lebih tinggi berbanding dengan GAC komersial. Hal ini telah membuktikan bahawa kapasiti penjerapan kedua-dua ACNFs yang diperbuat daripada kaedah 
putaran elektro (ACNFs/MgO dan ACNFs) terhadap ion (II) kadmium adalah lebih tinggi jika dibandingkan dengan kapasiti penjerapan GAC.

Kata kunci: poliakrilonitril, karbon nano-gentian teraktif, magnesium oksida, penjerapan ion kadmium (II)

\section{Introduction}

Nowadays, water contamination by heavy metals remains a major environmental concern as heavy metals persistently present in water subjected by their non-degradable properties [1]. Besides, their tendency to being overaccumulated in biosystem will negatively affect public health and environment despite they play roles in biochemical processes at trace level $[2,3,4]$. Among the common heavy metals that present in water, cadmium $(\mathrm{Cd})$ has attracted great attention for the studies of its removal as this metal are proved to pose adverse effects on human health even at minimum level [5]. Moreover, the emission of $\mathrm{Cd}$ may occur naturally or anthropogenically.

Various methods have been implied upon removal of cadmium laden in water streams such as ion exchange, precipitation, coagulation-flocculation and flotation where each of this method possesses their own limitations more likely to be incomplete removal, generation of secondary waste and inefficient removal efficacies [6,7]. Adsorption is another technique that is frequently applied for removal of heavy metals laden in water. There is wide range of adsorbents available; one good example is activated carbon nanofibers (ACNFs) as it has small inter-fibrous pore size with high porosity and also high specific surface area per unit mass that will lead to high adsorption capacity [8]. One of the challenges to activate the nanofibers is to increase the SSA and capacitance without damaging the graphitic fiber structure, which controls their mechanical properties [9].

Many polymers can be used for preparation of carbon nanofibers such as polyacrylonitrile (PAN), pitch and cellulose. Out of the aforementioned polymers, PAN is an excellent polymer selection because of its outstanding properties which contains a proper functional group(s), adsorbent for metal ion removal, inexpensive, common commercial product and can easily prepared into nanofibers by electrospinning. Preparation of ACNFs with incorporation of nano-scaled metal oxides such as magnesium oxide (MgO) has received great attention as it can solve the major concern of large pores of ACNFs upon removal of heavy metals. Moreover, many previous studies have been conducted on sole $\mathrm{MgO}$ due to its large SSA and were proven to be good adsorbent [10]. Thus, in this study the adsorption capacity of prepared $\mathrm{ACNF} / \mathrm{MgO}$ were determined and compared with neat PAN-based ACNFs and commercial granular activated carbon (GAC).

\section{Materials}

\section{Materials and Methods}

Polyacrylonitrile (PAN) with MW of 150, 000 was purchased from Sigma-Aldrich. Dimethylformamide (DMF; $\sim 99.98 \%$ purity), magnesium oxides ( $\mathrm{MgO}, \geq 99 \%$ trace metal basis) and activated carbon (GAC, untreated, granular, 8-20 mesh) were also purchased from Sigma-Aldrich (USA). Stock solution of $1000 \mathrm{mg} / \mathrm{L}$ cadmium ions was prepared by using analytical grade cadmium (II) chloride, which was further diluted to the required concentrations before used.

\section{Preparation of PAN nanofibers with dimethylformamide and metal oxides}

The dope solution was prepared by adding $1 \mathrm{wt} \%$ of $\mathrm{MgO}$ into $89 \mathrm{wt} \%$ of DMF. The mixture was stirred for at least 5 hours to ensure the $\mathrm{MgO}$ dispersed well in the solution before adding up the PAN $10 \mathrm{wt} \%$. The dope was left to stir for 24 hours. The electrospinning process was carried out at fixed electric field of $12 \mathrm{kV}$, the infusion rate is 1 $\mathrm{ml} /$ hour and the distance of the tip of needle to the collector is $20 \mathrm{~cm}$, where aluminium foils were used as the collectors.

\section{Activation of PAN-based carbon nanofibers}

In stabilization process, the nanofibers were heated up until $275{ }^{\circ} \mathrm{C}$ in the furnace (Carbolite) from room temperature with pure air gas flow rate of $0.2 \mathrm{~L} / \mathrm{min}$ at heating rate of $2^{\circ} \mathrm{C} / \mathrm{min}$ with resting time of $30 \mathrm{minutes}$ at $275^{\circ} \mathrm{C}$. The treated nanofibers were further heated up until $600{ }^{\circ} \mathrm{C}$ with nitrogen gas flow rate of $0.2 \mathrm{~L} / \mathrm{min}$ at heating rate of $5^{\circ} \mathrm{C} / \mathrm{min}$ with 30 minutes of dwelling time and were left for cooling down until room temperature. 
For activation process, the carbonized nanofibers were burnt in the tube furnace until $800{ }^{\circ} \mathrm{C}$ at rate of $5{ }^{\circ} \mathrm{C} / \mathrm{min}$ with carbon dioxide gas flow rate of $0.2 \mathrm{~L} / \mathrm{min}$ and 30 minutes of dwelling time.

\section{Characterization}

The surface properties, such as morphology and composition of various adsorbents were determined using scanning electron microscopy (SEM) and the specific surface area were investigated using nitrogen adsorption BrunauerEmmett-Teller (BET). Fourier Transform Infrared (FTIR) analysis was used to analyze the functional groups appeared in the ACNFs.

\section{Batch adsorption study}

Adsorption study of $\mathrm{Cd}$ ions was analyzed by investigating the effect of initial concentration upon adsorption rate of Cd. $0.05 \mathrm{~g}$ of the prepared samples were placed into conical flask containing $50 \mathrm{~mL}$ of Cd solution with initial concentration of $3 \mathrm{ppm}$ respectively. The samples were agitated on rotary shaker with the speed of $180 \mathrm{rpm}$ at $30{ }^{\circ} \mathrm{C}$ for 48 hours to reach equilibrium $[11,12]$. The sample solutions were later filtered and examined by using Atomic Absorption Spectrometer (AAS).

The adsorption capacity of the GAC, ACNFs and ACNFs/MgO and the percentage of removal of metallic ions by adsorbent were calculated by following Equation (1) [13].

$$
\mathrm{q}_{\mathrm{t}}=\frac{\left(C_{0}-C_{t}\right) V}{W}
$$

and the removal efficiency was calculated using Equation (2).

$$
\mathrm{R}(\%)=\frac{\left(C_{0}-C_{t}\right)}{C_{0}} \times 100
$$

where $C_{o}$ and $C_{t}$ are the initial and final concentration of the metallic solution $(\mathrm{mg} / \mathrm{L}), \mathrm{V}$ is the volume of the solution (L), and $\mathrm{M}$ is the weight of the adsorbent used $(\mathrm{g})$ [11].

For batch adsorption study, the ACNFs were rinsed with distilled water in order to eliminate any residual solutions. Then, the ACNFs were further dried in oven at room temperature. Desorption of ACNFs have been used to identify the recovery rate and reusability PAN-based $\mathrm{ACNFs} / \mathrm{MgO}$. Desorption of metal ions were carried out by immersing the ACNFs in $1 \mathrm{M} \mathrm{HCl}$ and agitated at $30{ }^{\circ} \mathrm{C}$ with speed of $100 \mathrm{rpm}$ for $5 \mathrm{~h}$. The concentration of Cd ions in the solution was analyzed using atomic absorption spectrometer (AAS) and the desorption ratio (D) was calculated as Equation 3 follows:

$$
\mathrm{D}(\%)=\frac{m g \text { ofmetal desorbed }}{m g \text { of metal ion adsorbed into ACNFS }} \times 100
$$

\section{SEM for morphology characterization}

\section{Results and Discussion}

Figure 1 ( $a$ and $b$ ) showed that both neat PAN-based ACNFs and modified ACNFs (ACNFs/MgO) possessed straight line fibers, bent fibers, rougher and wrinkled fibers due to the shrinkage effect during pyrolysis process. Moreover, in Figure 1(b), the presence of MgO in the ACNFs can be observed by the presence of white spots while the appearance of few beads was believed due to capillary instability [14] during electrospinning. 


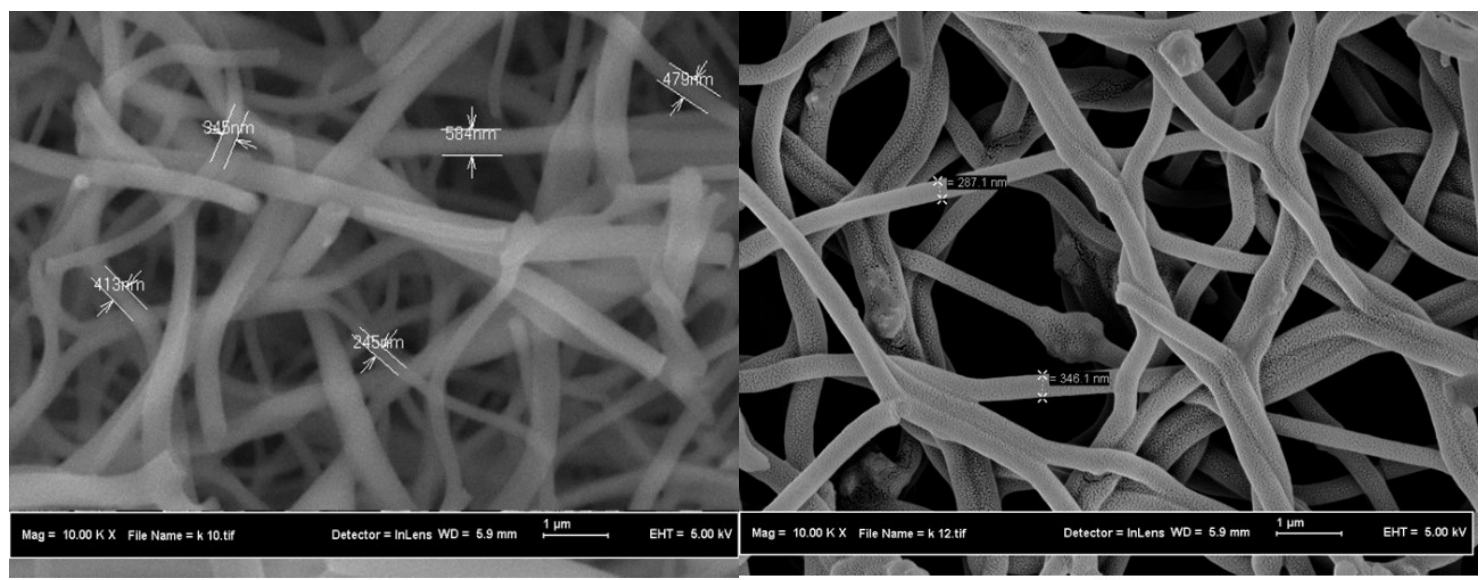

(a)

(b)

Figure 1. SEM images of (a) ACNFs; and (b) ACNFs/MgO with 10000x magnification

Meanwhile, in comparison of physical observation of SEM micrographs between neat ACNFs and ACNFs/MgO, it can be found that the average diameter of ACNFs without metal oxide is 413.2 $\pm 128.8 \mathrm{~nm}$ (Figure 1a) while for $\mathrm{ACNF}$ with $\mathrm{MgO}$ is $316.6 \pm 41.72 \mathrm{~nm}$ as shown in Figure $1(\mathrm{~b})$. As expected, the diameter of $\mathrm{ACNFs} / \mathrm{MgO}$ is smaller compared to the neat ACNF, as smaller diameter will lead to larger SSA $[15,16]$. However, even the diameter of the ACNFs obtained not in nano-meter range (below $100 \mathrm{~nm}$ ), still this study was a success as this result is comparable to other studies on ACNFs.

\section{BET analysis for specific surface area}

In this study, the single point BET method was employed to analyze nitrogen adsorption isotherms in order to determine the specific surface area (SSA) of ACNFs and ACNFs/MgO compared to commercial GAC.

Table 1. BET specific surface area of GAC, ACNF, ACNF/MgO

\begin{tabular}{lc}
\hline Samples & BET surface area $\left(\mathbf{m}^{2} / \mathbf{g}\right)$ \\
\hline $\mathrm{GAC}$ & 729.82 \\
$\mathrm{ACNF}$ & 15.43 \\
$\mathrm{ACNF} / \mathrm{MgO}$ & 198.80 \\
\hline
\end{tabular}

From Table 1, the pristine ACNFs show the lowest SSA of $15.43 \mathrm{~m}^{2} / \mathrm{g}$ while GAC has the highest SSA of 752.60 $\mathrm{m}^{2} / \mathrm{g}$. Theoretically, the SSA of both ACNFs and ACNFs/MgO were expected to be much higher compared to the results obtained as tabulated in Table 1. For instance, in a study conducted by Dadvar et al. [17], they have obtained SSA of ACNFs $/ \mathrm{MgO}$ of $600 \mathrm{~m}^{2} / \mathrm{g}$ and it was expected in future study, the results for ACNFs/MgO at least comparable or exceeded this value. The low SSA obtained in this study might be due to the incomplete pyrolysis process where the temperature used not high enough to create new micropores instead creating macro- and mesopores that led to low SSA. In our future study, the higher activation temperature with slower heating rate will be used in order to make sure the nanofibers undergo complete pyrolysis stage $[18,19]$.

\section{FTIR for functional group studies}

Typically, PAN-based nanofibers will show the existence of $\mathrm{CH}_{2}, \mathrm{C} \equiv \mathrm{N}, \mathrm{C}=\mathrm{O}, \mathrm{C}-\mathrm{O}$ and $\mathrm{C}-\mathrm{H}$ bonds but after activation all of these transition compounds were expected to evolve as volatilities and only carbon and hydrogen 
atoms remain [20]. As shown in Figure 2, there are six major peaks observed located at 2330.98, 2115.36, 1997.37, $1791.34,1095.37$ and $476.12 \mathrm{~cm}^{-1}$. The peak $2330.98 \mathrm{~cm}^{-1}$ is assigned as $\mathrm{O}-\mathrm{H}$ stretch from strongly hydrogenbonded- $\mathrm{COOH}$. Peaks 2115.36 and $1997.37 \mathrm{~cm}^{-1}$ basically attributed to the strong stretching of $\mathrm{C}=\mathrm{C}$ groups while peaks $1791.34 \mathrm{~cm}^{-1}$ and $1095.37 \mathrm{~cm}^{-1}$ indicated as stretching vibrations of C-O groups and C-C stretching, respectively. Last of all, peak $476.12 \mathrm{~cm}^{-1}$ were the proofs of the existence of $\mathrm{MgO}$ in the ACNFs as the MgO bonds are expected to be presence in the range of $600-450 \mathrm{~cm}-1$ [21]. These detected functional groups may play vital role for adsorption of $\mathrm{Cd}(\mathrm{II})$.

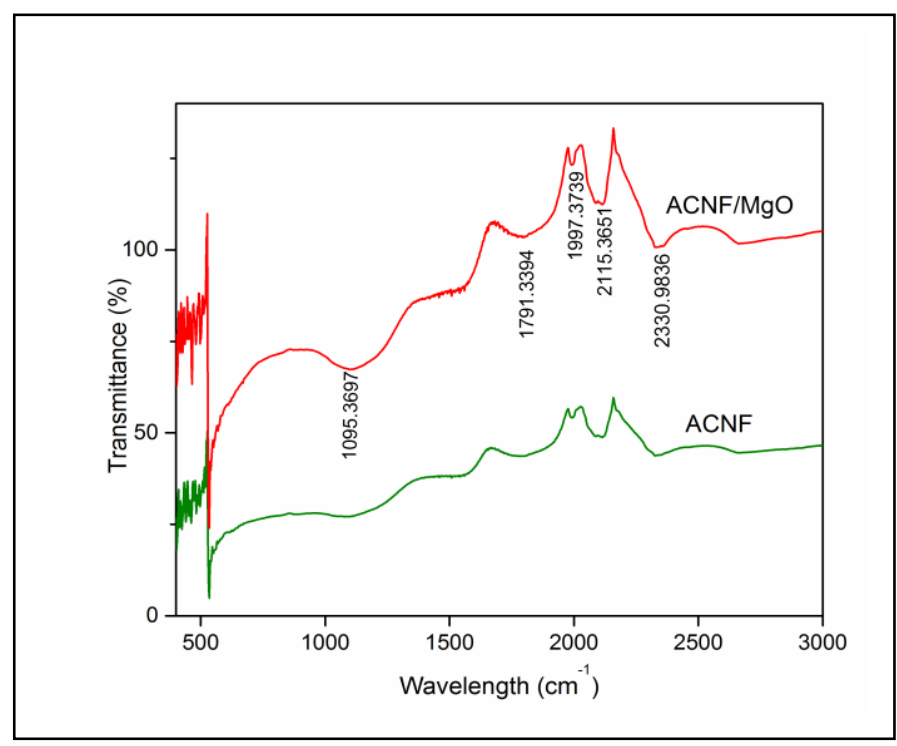

Figure 2. FTIR spectrum of both $\mathrm{ACNF}$ and $\mathrm{ACNF} / \mathrm{MgO}$

\section{Batch adsorption studies}

In this research, the adsorption of heavy metals onto activated carbon nanofibers has been studied using batchadsorption technique. This study was carried out to examine the adsorption performance of GAC, ACNFs and $\mathrm{ACNFs} / \mathrm{MgO}$ for the removal of $\mathrm{Cd}$ from aqueous solution.

Table 2 shows the percentage removal of cadmium for GAC, ACNFs and ACNFs/MgO it show promising results of $97 \%, 100 \%$ and $100 \%$, respectively. The obtained results revealed that both ACNFs and ACNFs/MgO has good adsorption capacity and effective for the removal of heavy metals from wastewater. Moreover, previous studies have shown that $\mathrm{MgO}$ was one of the good adsorbent with high SSA and the incorporation between ACNFs and $\mathrm{MgO}$ has proven to be good adsorbent [22] for Cd removal. Based on the results obtained, it can be said that both $\mathrm{ACNF}$ and $\mathrm{ACNFs} / \mathrm{MgO}$ can be good adsorbent for $\mathrm{Cd}$ removal.

Table 2. Removal of cd on GAC, ACNF AND ACNF/MgO

\begin{tabular}{lc}
\hline Samples & Removal of Cd (\%) \\
\hline GAC & 97 \\
ACNF & 100 \\
ACNF/MgO & 100 \\
\hline
\end{tabular}




\section{Conclusion}

This study investigated the adsorption capabilities of different types of activated carbon on cadmium as a function of adsorbent. Although GAC showed highest SSA compared to both ACNFs, however it was found that pristine and modified ACNFs provided better performance compared to commercial GAC in removal of cadmium from aqueous solution.

\section{Acknowledgement}

The authors would like to acknowledge the financial support from the Malaysian Ministry of Education and Universiti Teknologi Malaysia under GUP grants (Q.J130000.2542.05H46 and Q.J130000.2546.12H54) and HICOE grant (R.J090301.7846.4J179). The author would also like to acknowledge the technical and management support from Research Management Centre (RMC), Universiti Teknologi Malaysia.

\section{References}

1. Li Y., Wang Y.B., Gou X., Su Y.B. and Wang G. (2006). Risk assessment of heavy metals in soils and vegetables around non-ferrous metals mining and smelting sites, Baiyin, China. Journal of Environmental Sciences, 18(6): $1124-1134$.

2. Kumar R., Isloor A. M., Ismail A. F. and Matsuura T. (2013). Synthesis and characterization of novel water soluble derivative of chitosan as an additive for polysulfone ultrafiltration membrane. Journal of Membrane Science, 40: 140 - 147.

3. Meybeck M., Kuusisto A., Makela A. and Malkki R. (1996). Water quality monitoring: a practical guide to the design and implications of freshwater quality studies and monitoring programmes, Water quality. Eds. London, UK: Chapman and Hall.

4. Saeed K., Park S.Y. and Oh T. J. (2012). Preparation of hydrazine-modified polyacrylonitrile nanofibers for the extraction of metal ions from aqueous media. Journal of Applied Polymer Science, 121(2): 869 - 873.

5. Vila G., Luger A. and Clodi M. (2012). B-type natriuretic peptide modulates ghrelin, hunger, and satiety in healthy men. Diabetes, 61: $2592-2596$.

6. Barakat M. A. (2011). New trends in removing heavy metal from industrial wastewater. Arabic Journal of Chemical, 4: $38-41$.

7. Fu F. and Wang Q. (2011). Removal of heavy metal ions from wastewater: A review. Journal of Environment Management, $92: 20-25$.

8. Liang Y., Wu D. and Fu R. (2013). Carbon microfibers with hierarchical porous structure from electrospun fiber-like natural biopolymer. Scientic Reports, 3: 1119- 1124.

9. Mao X., Hatton T. and Rutledge G. (2013). A review of electrospun carbon fibers as electrode materials for energy storage. Current Organic Chemistry, 17(13): 1390 - 1401.

10. Zahida R., Rabia N., Durr-e-Shahwar, Muhammad Raza S. and Shujat A. (2014). Utilization of magnesium and zinc oxide nano-adsorbents as potential materials for treatment of copper electroplating industry wastewater. Journal of Environmental Chemical Engineering, 2(1): 642 - 651.

11. Desta M. B. (2013). Batch sorption experiments: Langmuir and Freundlich isotherm studies for the adsorption of textile metal ions onto teff straw agricultural waste. Journal of Thermodynamics, 2013: $1-6$.

12. Vijayakumar G., Tamilarasan R. and Dharmendirakumar M. (2012). Adsorption, kinetic, equilibrium and thermodynamic studies on the removal of basic dye rhodamine-B from aqueous solution by the use of natural adsorbent perlite. Journal of Materials and Environmental Science, 3(1): 157 - 170.

13. Kampalanonwat P. and Supaphol P. (2014). The study of competitive adsorption of heavy metal ions from aqueous solution by aminated polyacrylonitrile nanofibers mat. Energy Procedia, 56: $142-151$.

14. Zussman E., Chen X., Ding W., Calabri L., Dikin D. A., Quintana J. P. and Ruoff R. S. (2005). Mechanical and structural characterization of electrospun PAN-derived carbon nanofibers. Carbon, 43: 2175 - 2185.

15. Huang Z. M., Zhang Y. Z., Kotaki M. and Ramakrishna S. (2003). A review on polymer nanofibers by electrospinning and their applications in nanocomposites. Composites Science and Technology, 63(15): 2223 - 2253.

16. Drew C., Liu X., Ziegler D., Wang X.Y., Bruno F. F., Whitten J., Samuelson L. A. and Kumar J. (2003). Metal oxide-coated polymer nanofibers. American Chemical Society, 3(2): 143 - 147.

17. Dadvar S., Tavanai H. and Morshed M. (2012). Effect of embedding $\mathrm{MgO}$ and $\mathrm{Al}_{2} \mathrm{O}_{3}$ nanoparticles in the precursor on the pore characteristics of PAN based activated carbon nanofibers. Journal of Analytical and Applied Pyrolysis, 98: 98 - 105. 
18. Abdullah A. H., Kassim A., Zainal Z., Hussein M. Z., Kuang D., Ahmad F. and Wooi O.S. (2001). Preparation and characterization of activated carbon from gelam wood bark. Malaysian Journal of Analytical Sciences, 7(1): $65-68$.

19. Bonso J. S., Kalaw G. D. and Ferraris J. P. (2014). High surface area carbon nanofibers derived from electrospun PIM-1 for energy storage applications. Journal of Materials Chemistry A, 2: 418 - 424.

20. Arshad S. N., Naraghi M. and Chasiotis I. (2011). Strong carbon nanofibers from electrospun polyacrylonitrile, Carbon, 49: $1710-1719$.

21. Hofmeister M., Keppel E. and Speck K. (2003). Adsorption and reflection infrared spectra of MgO and other diatomic compounds. Monthly Notices of the Royal Astronomical Society, 345(1): 16 - 38.

22. Rajagopalan S., Koper O., Decker S. and Klabunde K. J. (2002). Nanocrystalline metal oxides as destructive adsorbents for organophosphorus compounds at ambient temperatures. Chemistry-A European Journal, 8(11): $2602-2607$. 